\title{
DIDAKTIČKI ASPEKT REALIZACIJE OBRAZOVANJA ZA ODRŽIVI RAZVOJ U KURIKULUMIMA SAVREMENE ŠKOLE
}

U radu će biti predstavljen koncept održivog razvoja u kontekstu obrazovanja i dat prikaz obrazovanja za održivi razvoj u obrazovnim sistemima Srbije, Crne Gore i Hrvatske kroz komparativnu perspektivu izbornog programa Obrazovanje za održivi razvoj (Srbija), međupredmetne oblasti Obrazovanje za održivi razvoj (Crna Gora) i međupredmetne teme Održivi razvoj (Hrvatska). Kao kriterijumi komparativne analize korišćena su didaktička obeležja realizacije analiziranih programa: nastavne teme i sadržaji; načini realizacije $s$ naglaskom na metode, tehnike i modele rada; uloga nastavnika i načini evaluacije učeničkih postignuća. Rezultati sprovedene analize ukazuju na značajne sličnosti ali i razlike u didaktičkim aspektima realizacije obrazovanja za održivi razvoj u Srbiji, Crnoj Gori i Hrvatskoj. Utvrđene sličnosti odnose se na način realizacije koji je usmeren na iskustveno učenje i aktivistički i stvaralački pristup učenika, kao i ulogu nastavnika koja je prevashodno moderatorska, instruktivna i pomagačka. Najizraženije razlike u didaktičkom aspektu obrazovanja za održivi razvoj analiziranih školskih sistema predstavljaju jednodimenzionalnost nastavnih sadržaja u sagledavanju ovog koncepta u Srbiji, koju takođe, u odnosu na susedne zemlje, karakteriše nedovoljna specifikacija načina ocenjivanja učenika u ovoj oblasti.

Ključne reči: didaktički aspekt, obrazovanje, održivi razvoj, kurikulum, savremena škola.

\section{ODRŽIVI RAZVOJU KONTEKSTU OBRAZOVANJA}

Održivi razvoj kao koncept zahteva sagledavanje granica prirodnih resursa, kapaciteta ekosistema, te interakcije koja se uspostavlja između društvenih, ekonomskih, političkih sistema i sistema životne sredine (Stanišić, 2016). On ne znači samo napredak u postizanju jednakosti kada je reč o siromaštvu, gladi,

\footnotetext{
*tamaravukic93@gmail.com
} 
obrazovanju, zdravstvenoj zaštiti i zaštiti životne sredine, već uključuje i pitanja kao što su održivi obrasci proizvodnje i potrošnje, dobrog upravljanja, otvorene i odgovorne vlade, te politika koje ublažavaju posledice sukoba, nasilja i narušavanja ljudskih prava. Suočavanje sa ovim i drugim izazovima zahteva aktivne i odgovorne građane, osposobljene da donose odluke uzimajući u obzir buduće posledice, sa stavovima i vrednostima utemeljenim na dobrom poznavanju koncepta održivog razvoja (Benavot, 2014). Njihovo osposobljavanje zahteva promenu u stavovima i ponašanjima koja se može ostvariti putem obrazovanja (Martins-Mata, \& Costa, 2006).

Značaj obrazovanja u kontekstu održivog razvoja ogleda se u kritičnoj ulozi za oblikovanje individualnih i kolektivnih znanja, veština, vrednosti i stavova koji podržavaju kretanje putem održivosti i koji su osnova odgovornog građanstva, te $u$ tome što obrazovanje samo po sebi predstavlja katalizator razvoja - obrazovanje determiniše društvene i ekonomske promene i osnova je za postizanje mira, tolerancije i održivosti (Osman-Ladhani-Findlater, \& McKay, 2017).

Obrazovanje za održivi razvoj predstavlja svojevrsnu evoluciju obrazovanja za zaštitu životne sredine, odnosno stvaranje integrativne perspektive održivog razvoja u čijem fokusu su, pored životne sredine, i socijalna i ekonomska dimenzija (Didham-Ofei-Manu, 2015). Tako je formiran, sada već sveprisutan, termin obrazovanje za održivi razvoj, predstavljen u dokumentu Agenda 21 od strane Ujedinjenih Nacija 1992. godine (Taylor et al., 2019). Poglavlje 36 („Unapređivanje obrazovanja, obuke i društvene svesti“) Agende 21 je u potpunosti posvećeno obrazovanju koje je prepoznato kao ključni faktor za postizanje održivog razvoja (Rieckmann, 2012).

$\mathrm{Na}$ Svetskom Samitu o održivom razvoju održanom 2002. godine u Johanesburgu data je preporuka da se usvoji Dekada obrazovanja za održivi razvoj od 2005. do 2014. godine (Calder-Clugston, 2003) čime je ostvarena dalja podrška UN inicijativama usmerenim ka jačanju obrazovanja za održivi razvoj (BagolySimó, 2013). Sveopšti cilj Dekade se ogleda u ,integraciji vrednosti svojstvenih održivom razvoju u sve aspekte učenja, kako bi se podstakle promene u ponašanju koje vode ka održivijem i pravednijem društvu za sve“ (UN, 2005: 5).

Aktuelnosti obrazovanja za održivi razvoj nakon Dekade posebno je doprineo dokument Agenda 2030 zahvaljujući kojoj je obrazovanje za održivi razvoj postalo glavna tema $\mathrm{u}$ oblasti obrazovanja na globalnom nivou (MulàDlouhý, \& Alba, 2017). U ovom dokumentu definiše se održivi razvoj za period nakon 2015. godine kroz 17 globalnih ciljeva. Jedan od tih ciljeva naglašava ulogu obrazovanja u postizanju društveno-ekonomskog i političkog razvoja (Ifegbesan- 
Lawak, \& Rampedi, 2017). Reč je o cilju 4 koji je definisan kao: „osigurati inkluzivno i pravedno kvalitetno obrazovanje i promovisati mogućnosti celoživotnog učenja za sve“ (UN, 2015: 14).

Navedena i druga dokumenta, konferencije i deklaracije u oblasti održivog razvoja, te dominantna uloga obrazovanja za postizanje ciljeva koje ovaj koncept podržava, doprineli su tome da održivi razvoj postane sastavni deo kurikuluma. Govori se o dva načina integracije održivog razvoja u kurikulum: horizontalnom i vertikalnom. Horizontalna integracija podrazumeva neki vid prožimanja različitih predmeta održivim razvojem, dok se vertikalna integracija može razumeti kao organizovanje posebnih kurseva/predmeta koji se bave problematikom održivog razvoja (Ceulemans-De Prins, 2010).

Ukoliko obrazovanje za održivi razvoj „prati“ učenike na svakom nivou obrazovanja, veći će biti i njegov uticaj (UNESCO, 2005). Međutim, problem je to što različiti nivoi obrazovanja nisu integrisani, a nedostaje $i$ koherentni i odgovarajući pristup obrazovanju za održivi razvoj. Potrebna je preorijentacija obrazovnog sistema i implementacija novih kurseva i/ili predmeta u kurikulume i u stručno usavršavanje (Martins et al., 2006). Pri tom, potrebno je posebnu pažnju posvetiti nastavnicima, s obzirom na to da su prepoznati kao „kritični agenti““ obrazovanja za održivi razvoj (Ifegbesan et al., 2017). Oni moraju biti uvereni u potrebu obrazovanja za održivi razvoj i biti „naoružani““ strategijama za njegovu integraciju u nastavu. Važno je imati na umu da obrazovanje za održivi razvoj ne treba posmatrati kao „samo još jedan predmet“ koji je potrebno integrisati u već prenatrpani kurikulum. Ono mora prožimati celinu obrazovne institucije i postati kontekst u okviru koga se realizuju postojeći ciljevi obrazovanja (UNESCO, 2005).

\section{OBRAZOVANJE ZA ODRŽIVI RAZVOJ U KURIKULUMIMA SAVREMENE ŠKOLE: STANJE U SRBIJI, CRNOJ GORI I HRVATSKOJ}

Savremeni kurikulum osnovne škole u Srbiji ne predviđa poseban predmet posvećen održivom razvoju, ali analiza nastavnih programa predmetne i razredne nastave pokazuje da se učenici sa nekim temama iz oblasti održivog razvoja susreću u predmetima Svet oko nas, Priroda i društvo, Građansko vaspitanje, Geografija, Biologija, Tehnika i tehnologija, Fizika i Hemija (Službeni glasnik RS, br. 10/17; 16/18; 5/19; 11/19; 15/18).

Srednje stručno obrazovanje, s druge strane, pruža veće mogućnosti za upoznavanje sa održivim razvojem, makar sa dimenzijom životne sredine, jer gotovo sva obrazovna područja obuhvataju predmet Ekologija i zaštita životne sredine. U nastavnim programima postoje i drugi predmeti posvećeni zaštiti životne 
sredine, dok neki obrazovni profili obuhvataju predmete/module koji se konkretno odnose na održivi razvoj: Održivi razvoj u građevinarstvu (geodezija i građevinarstvo), Održiv razvoj Republike Srbije (ekonomija, pravo i administracija), Održivi razvoj (hemija, nemetali i grafičarstvo), Energetska efikasnost i održivi razvoj (geologija, rudarstvo i metalurgija), Održivi dizajn (šumarstvo i obrada drveta) (Službeni glasnik RS, br. 7/18; 15/15; 12/15; 5/17; 6/15).

U gimnazijama se održivi razvoj izučava u okviru geografije, biologije i hemije, ali i kroz izborni program posebno posvećen problematici održivog razvoja - Obrazovanje za održivi razvoj koji se izučava od školske 2018/19. godine (Službeni glasnik RS, br. 12/18).

U Crnoj Gori su sadržaji iz oblasti održivog razvoja uvedeni kao međupredmetna oblast Obrazovanje za održivi razvoj kroz celokupan kurikulum, pri čemu se naglašava da fokus ostaje na pojedinačnim predmetima, uz istovremeno multidisciplinarno sagledavanje problema sa različitih perspektiva (ČabriloLalović-Sudar, i Vasiljević, 2015).

U Hrvatskoj se od školske 2019/20. godine u osnovnim i srednjim školama primenjuje kurikulum za međupredmetnu temu Održivi razvoj koja pored dimenzije zaštite životne sredine, obuhvata i ekonomsku i socijalnu dimenziju (Narodne novine, br. 7/2019).

U nastavku su kroz kategorije nastavne teme i sadržaji, način realizacije, uloga nastavnika i ocenjivanje učenika, komparativno prikazani izborni program Obrazovanje za održivi razvoj (Srbija), međupredmetna oblast Obrazovanje za održivi razvoj (Crna Gora) i međupredmetna tema Održivi razvoj (Hrvatska).

\section{Nastavne teme i sadržaji}

Izborni program Obrazovanje za održivi razvoj za prvi razred gimnazije obuhvata teme Voda, Vazduh i Održivi gradovi i naselja. Za svaku od njih sadržaji su dati u vidu pitanja (npr. Kakvu vodu pijemo?; Kako naša škola može postati održiva?), a koje nastavnik može dopuniti, s obzirom na to da se teme mogu proučavati sa različitih stanovišta (Službeni glasnik RS, br. 12/18).

U okviru dokumenata Međupredmetne oblasti u predmetnim programima za osnovnu školu i gimnaziju u Crnoj Gori (Čabrilo i dr., 2014a; Čabrilo i dr., 2014b) predviđeno je osam međupredmetnih tema: Klimatske promene, Zelena ekonomija, Zaštita životne sredine, Održivi gradovi i naselja, Biodiverzitet, Zdravstveno obrazovanje i vaspitanje, Obrazovanje za i o ljudskim pravima i Preduzetničko učenje. 
Tema Održivi gradovi i naselja, koju nalazimo i u okviru izbornog programa Obrazovanje za održivi razvoj u Srbiji za prvi razred gimnazije, kao međupredmetna oblast za sva četiri razreda gimnazije u Crnoj Gori postavljena je znatno šire, kada je reč o predviđenim sadržajima. Njihov pregled dat je u Tabeli 1.

Tabela 1. Tema Održivi gradovi i naselja: pregled sadržaja

\begin{tabular}{|c|c|}
\hline $\begin{array}{c}\text { Srbija } \\
\text { Izborni program } \\
\text { Obrazovanje za održivi razvoj }\end{array}$ & $\begin{array}{c}\text { Crna Gora } \\
\text { Međupredmetna oblast } \\
\text { Obrazovanje za održivi razvoj }\end{array}$ \\
\hline Sadržaji & Pojmovi/sadržaji \\
\hline $\begin{array}{l}\text {-šta su održivi gradovi? } \\
\text {-održivi gradovi i naselja u svetu } \\
\text {-po čemu se razlikuje kvalitet života u } \\
\text { našem mestu nekad i sad: prirodni } \\
\text { resursi, ekonomija, kultura, ponašanje } \\
\text { ljudi? } \\
\text {-šta zgrade i kuće čini održivim? } \\
\text {-kako nastaju urbana ostrva toplote? } \\
\text {-šta sve podrazumeva dobrobit životinja } \\
\text { u naseljenim mestima? } \\
\text {-kako naša škola može postati održiva? }\end{array}$ & $\begin{array}{l}\text { sveobuhvatno planiranje i pristup upravljanju; } \\
\text { ekonomska, socijalna i ekološka održivost; } \\
\text { bezbedno i zdravo životno okruženje; niska } \\
\text { emisija ugljenika; obnovljivi izvori energije; } \\
\text { energetska efikasnost; plan za održivo } \\
\text { upravljanje otpadom; mogućnosti pretvaranja } \\
\text { otpada u energiju; sigurno snabdevanje pijaćom } \\
\text { vodom; podsticanje održivog korišcenja vode; } \\
\text { prečišćavanje komunalnih otpadnih voda; } \\
\text { povećanje udela javnog prevoza; izgradnja } \\
\text { pešačkih i biciklističkih staza; smanjenje } \\
\text { upotrebe automobila i korišćenje autimobila sa } \\
\text { niskom emisijom ugljenika; integrisanje zelene } \\
\text { infrastrukture u urbanim sredinama i oko njih; } \\
\text { projektovanje zgrada sa smanjenom upotrebom } \\
\text { energije itd. }\end{array}$ \\
\hline
\end{tabular}

(Službeni glasnik RS, br. 12/18: 230; Čabrilo i dr., 2014b: 32-35)

Teme Voda i Vazduh koje su predviđene za izborni program Obrazovanje za održivi razvoj se u okviru međupredmetne oblasti Obrazovanje za održivi razvoj nalaze kao deo teme Zaštita životne sredine. U okviru izbornog programa Obrazovanje za održivi razvoj, za temu Voda predloženi su sadržaji koji naglasak stavljaju na vodu sa kojom učenici svakodnevno dolaze u dodir, odnosno na vodu iz okruženja. Tako bi učenici trebalo da dođu do saznanja o kvalitetu vode, izvorima zagađivanja i njihovom uticaju na vode u okruženju, uticaju deponija, poljoprivrede $\mathrm{i}$ industrije na zagađivanje vode u lokalnoj sredini, posledicama sredstava za čišćenje i pranje koja se koriste u domaćinstvu po životnu sredinu i zdravlje, neracionalnoj upotrebi vode i dr. (Službeni glasnik RS, br. 12/18). Sadržaji predviđeni za podtemu Voda u okviru međupredmetne oblasti Obrazovanje za održivi razvoj takođe uključuju saznanja o pojmovima koji se odnose na ispravnost vode, upotrebu vode i njeno zagađenje, domaćinstva, deponije, industriju i poljoprivredu i sl. Međutim, ova podtema obuhvata i sticanje širih znanja: 
Milenijumska deklaracija, površinske i podzemne vode, voda u našem organizmu, voda kao resurs, energija vode, biorazgradive i nerazgradive komponente, upotreba vode u rekreativne svrhe, sistemi za prečišćavanje vode itd. (Čabrilo i dr., 2014b). Što se tiče teme Vazduh, u okviru izbornog programa Obrazovanje za održivi razvoj, predviđeno je da učenici dođu do saznanja o kvalitetu vazduha, mogućnostima njegovog poboljšanja i upotrebi obnovljivih i neobnovljivih izvora energije iz perspektive zagađivanja vazduha (Službeni glasnik RS, br. 12/18). Slično tome, predviđeni operativni ciljevi za podtemu Vazduh u okviru međupredmetne oblasti Obrazovanje za održivi razvoj podrazumevaju upoznavanje sa izvorima zagađenja vazduha, analizu uticaja zagađujućih supstanci na kvalitet vazduha, upoređivanje kvaliteta vazduha $u$ zatvorenim $i$ otvorenim prostorima, predlaganje mera za smanjenje antropogenog zagađivanja vazduha, upoznavanje sa merama za zaštitu vazduha od zagađenja i dr. (Čabrilo i dr., 2014b).

Za međupredmetnu temu Održivi razvoj u Hrvatskoj su u okviru domena: Povezanost, Delovanje i Dobrobit predstavljeni ključni sadržaji po ciklusima obrazovanja (Tabela 2).

Tabela 2. Pregled ključnih sadržaja za međupredmetnu temu Održivi razvoj

\begin{tabular}{|c|c|c|c|}
\hline & POVEZANOST & DELOVANJE & DOBROBIT \\
\hline 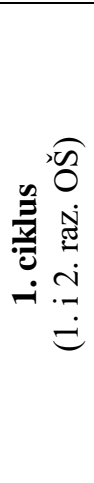 & $\begin{array}{l}\text { obavezni: } \\
\text { međujednica, } \\
\text { razlike, raznolikost u } \\
\text { prirodi, povezanost } \\
\text { boravka u prirodi i } \\
\text { zdravlja }\end{array}$ & 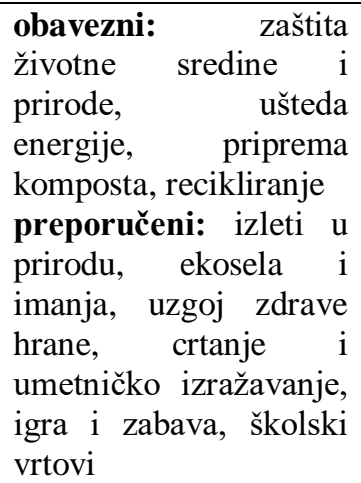 & $\begin{array}{l}\text { obavezni: odnos } \\
\text { čoveka prema prirodi i } \\
\text { životinjama, porodični } \\
\text { i međuljudski odnosi, } \\
\text { nenasilno rešavanje } \\
\text { sukoba } \\
\text { preporučeni: direktna } \\
\text { komunikacija, empatija }\end{array}$ \\
\hline 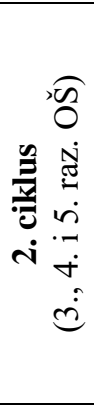 & $\begin{array}{l}\text { obavezni: obnovljivi i } \\
\text { neobnovljivi izvori } \\
\text { energije, } \\
\text { resursi, ljudski uticaj na } \\
\text { prirodu, međudelovanje } \\
\text { u prirodi } \\
\text { preporučeni: izvori } \\
\text { energije i podneblje, } \\
\text { termički izolatori }\end{array}$ & 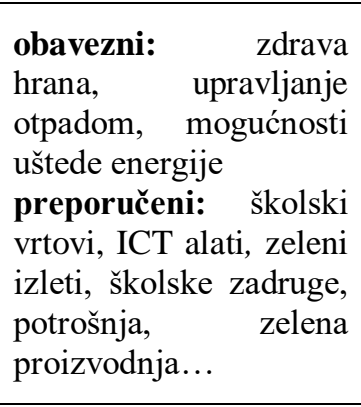 & $\begin{array}{l}\text { obavezni: društvena } \\
\text { (ne)pravda, } \\
\text { solidarnost, ljudska } \\
\text { prava, lična i opšta } \\
\text { dobrobit, prava } \\
\text { životinja, (ne)zagađena } \\
\text { životna sredina, otpad } \\
\text { preporučeni: buka, } \\
\text { svetlosno zagađenje, } \\
\text { pesticidi i đubriva }\end{array}$ \\
\hline
\end{tabular}




\begin{tabular}{|c|c|c|c|}
\hline 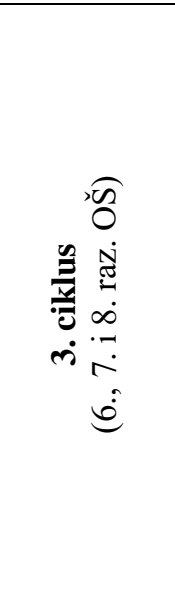 & 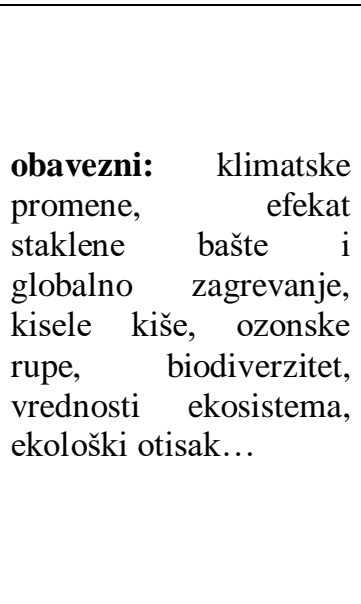 & 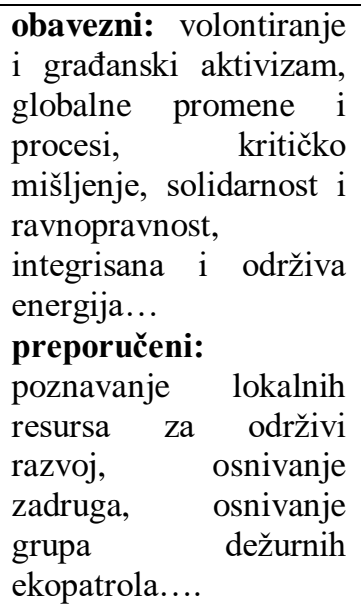 & $\begin{array}{lr}\text { obavezni: } & \text { ograničenje } \\
\text { prirodnih } & \text { resursa, } \\
\text { socijalne } & \text { politike, } \\
\text { politički } & \text { sistem, } \\
\text { demokratija, } & \text { kreiranje } \\
\text { politika i } & \text { politički } \\
\text { sistemi... } & \end{array}$ \\
\hline 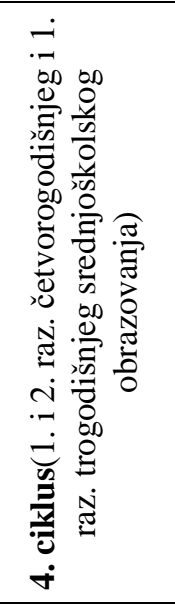 & $\begin{array}{l}\text { obavezni: uticaj ljudi i } \\
\text { ekonomije na održivi } \\
\text { razvoj, } \\
\text { politike, } \\
\text { pravda } \\
\text { preponomske } \\
\text { ravnoteža, } \\
\text { života, kvatska } \\
\text { stanište, resursi, biljne } \\
\text { vrste, ekosistem, } \\
\text { politički sistem }\end{array}$ & 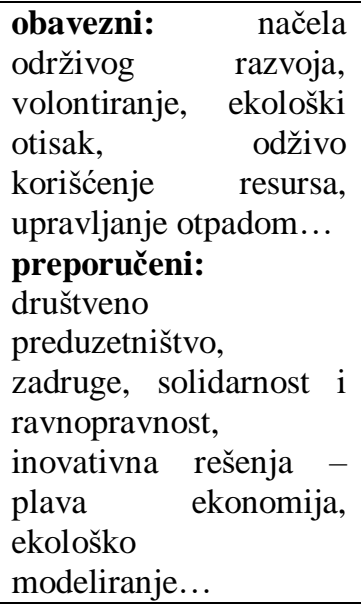 & $\begin{array}{lr}\text { obavezni: } & \text { kvalitet } \\
\text { života, javne } & \text { politike, } \\
\text { indeksi } & \text { društvenog } \\
\text { razvoja, } & \text { globalne } \\
\text { politike, } & \text { resursi, } \\
\text { ekološki otisak... } \\
\text { preporučeni: napredni } \\
\text { i novi ekonomski } \\
\text { razvojni r modeli, } \\
\text { sigurnost, } \\
\text { (ne)zagađena } \\
\text { sredina }\end{array}$ \\
\hline 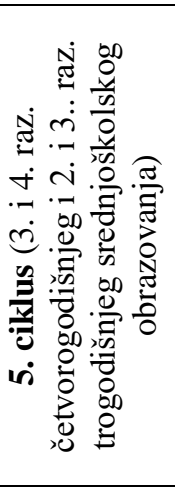 & $\begin{array}{l}\begin{array}{l}\text { obavezni: } \\
\text { promene, }\end{array} \\
\text { otisak, } \\
\text { ekološki } \\
\text { održiva } \\
\text { politički i ekonomski i potrošnja, } \\
\text { sistemi... } \\
\text { preporučeni: } \\
\text { tradicionalna } \\
\text { proizvodnja }\end{array}$ & $\begin{array}{lr}\text { obavezni: } & \begin{array}{r}\text { klimatska } \\
\text { pravda, }\end{array} \\
\text { delovanje } & \text { usmerentiranje, } \\
\text { prema } & \text { budućnosti, } \\
\text { primeri } & \text { održivog } \\
\text { dizajna } & \\
\text { preporučeni: } & \\
\text { društveno } & \\
\text { preduzetništvo, } \\
\text { zadruge, } & \text { građanski } \\
\text { aktivizam, } & \text { globalne } \\
\text { promene i procesi... }\end{array}$ & $\begin{array}{lr}\text { obavezni: } & \text { granica } \\
\text { raspoloživosti } & \\
\text { prirodnih } & \text { resursa, } \\
\text { ekološki } & \text { otisak, } \\
\text { ravnoteža i } & \text { kvalitet } \\
\text { ekosistema, } & \\
\text { volontiranje, } & \text { zdrava } \\
\text { ishrana i proizvodnja } \\
\text { hrane... } \\
\text { preporučeni: } \\
\text { energetska efikasnost }\end{array}$ \\
\hline
\end{tabular}

(Narodne novine, br. 7/2019)

Uska koncepcija sadržaja u okviru izbornog programa Obrazovanje za održivi razvoj u odnosu na međupredmetne oblasti u Crnoj Gori i Hrvatskoj sasvim 
je razumljiva, s obzirom na to da se ne odnosi na celokupan obrazovni sistem, i polazeći od toga da je reč o programu koji je izbornog karaktera.

\section{Način realizacije}

Realizacija sadržaja predviđenih u okviru izbornog programa Obrazovanje za održivi razvoj se temelji na istraživanju i osmišljavanju projekata čiji je cilj proizvod koji pruža informacije o određenoj temi. Predviđeno je da se učenici podele u manje grupe u okviru kojih će istraživati različite ili iste teme (sa drugačijeg aspekta). Teme se mogu istraživati na osnovu podataka sa Interneta, proučavanjem literature, kroz obilaske okruženja, posete institucijama, ali i ispitivanjem stavova, znanja, vrednosti vršnjaka, sugrađana, stručnjaka i sl. Rezultate svog istraživanja svaka grupa prezentuje ostalim učenicima, nakon čega se organizuje diskusija čiji je krajnji ishod odabir problema projekta. Projekat ima za cilj da učenike podstakne na razmišljanje o svom ponašanju, te na predlaganje i preduzimanje aktivnosti koje su korisne za okruženje. U skladu sa time, krajnji rezultat rada na projektu mogu biti informacije, filmovi, predstave, posteri, brošure, akcije i sl. u vezi sa zaštitom životne sredine. Rezultat svega toga jeste ugrađivanje principa održivosti u rad škola koje će okolini poslužiti kao primer održivog ponašanja (Službeni glasnik RS, 12/18).

Realizacija međupredmetne oblasti Obrazovanje za održivi razvoj u Crnoj Gori zahteva njeno uključivanje u plan rada škole, kroz sve nastavne predmete, kroz obavezne izborne sadržaje, saradnju sa lokalnom zajednicom, obeležavanje značajnih datuma, kontinuirani profesionalni razvoj nastavnika i primenu raznovrsnih nastavnih metoda (Čabrilo i dr., 2015).

Naglasak je, kao i u okviru izbornog programa Obrazovanje za održivi razvoj, na istraživačkim aktivnostima učenika, a posebno na aktivnom i iskustvenom učenju. Učenike je potrebno podstaći na promišljanje stvarnosti i na razvijanje svojih ideja i vrednosti kroz metode i tehnike aktivnog učenja (Tabela 3). Pored toga, učenje utemeljeno na iskustvu je neizostavno u obrazovanju za održivi razvoj, a zahteva kontakt učenika sa okruženjem. Predlažu se i participativno učenje, učenje zasnovano na resursima lokalne zajednice, učenje na otvorenom, učenje rešavanjem problema, studija slučaja, pitanja i analogije u nastavi, interaktivno i kooperativno učenje, diskusija (debata) i praktično učenje (ibid.).

$\mathrm{U}$ delu Učenje $i$ poučavanje međupredmetne teme u okviru Odluke o donošenju kurikuluma za međupredmetnu temu Održivi razvoj za osnovne i srednje škole u Republici Hrvatskoj (Narodne novine, br. 7/2019) se navodi da je zbog složenosti koncepta održivog razvoja značajno učenike upoznavati sa njime od 
prvog vaspitno-obrazovnog ciklusa (1. i 2. razred OŠ) kroz jednostavne primere, u skladu sa uzrastom učenika. Kao i u slučaju Crne Gore, predlaže se da učenje bude zasnovano na životnim situacijama i situacijama iz okruženja, ali i na hipotetičkim primerima, primenjujući metode aktivnog učenja (Tabela 3) koje, između ostalog, uključuju upravo izradu istraživačkih i dr. projekata, u čemu se ogleda sličnost sa izbornim programom Obrazovanje za održivi razvoj u Srbiji. I u ovom slučaju se preporučuje saradnja i poseta institucijama i organizacijama čiji je rad utemeljen na principima održivosti, a poseban naglasak je stavljen na integraciju ovih principa u rad škola. Kao i u okviru međupredmetne oblasti Obrazovanje za održivi razvoj u Crnoj Gori, i međupredmetna tema Održivi razvoj u Hrvatskoj zahteva aktivnog učenika koji istražuje teme u skladu sa svojim interesovanjima, predlažući ideje i rešenja u cilju održivosti. To se takođe poklapa sa projektima koje učenici izrađuju u okviru izbornog programa Obrazovanje za održivi razvoj u Srbiji, s obzirom na to da su usmereni na idejna rešenja za dobrobit zajednice i za održivi rad škole. Kako se radi o međupredmetnoj temi, ona je, kao i u slučaju Crne Gore, ugrađena u redovnu nastavu, ali su značajni i nastavni dani bez zvona, projektni dani ili nedelje, izvanučionička nastava, vannastavne aktivnosti i časovi razrednog starešine (ibid.).

U Tabeli 3 dat je prikaz metoda, tehnika i modela nastavnog rada predloženih za uspešnu realizaciju izbornog programa Obrazovanje za održivi razvoj, te međupredmetnih oblasti u Crnoj Gori i Hrvatskoj.

Tabela 3. Metode, tehnike i modeli nastavnog rada u oblasti održivog razvoja

\begin{tabular}{cl}
\hline & \multicolumn{1}{c}{ Metode, tehnike i modeli nastavnog rada } \\
\hline $\begin{array}{c}\text { Srbija } \\
\text { Izborni program } \\
\text { Obrazovanje za održivi } \\
\text { razvoj }\end{array}$ & -istraživanje, diskusija, izrada malih projekata \\
\hline $\begin{array}{c}\text { Crna Gora } \\
\text { Međupredmetna oblast } \\
\text { Obrazovanje za održivi } \\
\text { razvoj }\end{array}$ & $\begin{array}{l}\text {-rasprava, simulacija, igra uloga, modeliranje, upotreba ICT, } \\
\text { anketa, studija slučaja, ekskurzija, učenje na otvorenom, } \\
\text { rešavanje problema dobre prakse, iskustva na radnom mestu, }\end{array}$ \\
\hline $\begin{array}{c}\text { Hrvatska } \\
\text { Međupredmetna tema } \\
\text { Održivi razvoj }\end{array}$ & $\begin{array}{l}\text {-debata, igre u prostoru, scenski i likovni prikazi, saradničko } \\
\text { odbačenih i praktični radovi, upotreba prirodnih materijala, } \\
\text { izvanučionička nastava uz interdisciplinarni i multidisciplinarni } \\
\text { pristup učenju i poučavanju }\end{array}$ \\
\hline
\end{tabular}

(Službeni glasnik RS, br. 12/18; Narodne novine, br. 7/2019; Čabrilo i dr., 2015)

Kao i izborni program Obrazovanje za održivi razvoj, i međupredmetne oblasti u Crnoj Gori i Hrvatskoj zahtevaju aktivnog učenika, a predstavljene metode, tehnike i modeli rada su usklađene sa tim, s obzirom na to da se učenik 
može osposobiti za održivo ponašanje samo ukoliko je direktno uključen u svoje okruženje, ukoliko kritički pristupa problemima, nastojeći da, kroz saradnju sa drugima, pronađe neka nova rešenja.

\section{Uloga nastavnika}

Izborni program Obrazovanje za održivi razvoj od nastavnika zahteva da učenike zainteresuje za održivi razvoj, što služi kao osnova za njihovo aktivno delovanje u lokalnoj sredini, ne zanemarujući pri tom globalnu perspektivu. Nakon uvodnih aktivnosti u okviru kojih nastavnik upoznaje učenike sa programom i načnom rada, sledi prezentovanje tema. U okviru svake od njih, zadatak nastavnika je da učenike podstakne na diskusiju, a potom predstavlja teme najčešće u obliku problemskih pitanja. Učenike je potrebno podsticati da temu za istraživanje biraju na osnovu svojih interesovanja i pomoći im da odaberu odgovarajuće izvore i tehnike rada. Pri izradi projekta, nastavnik pomaže učenicima da definišu problem i cilj, te da projekat posmatraju kao doprinos kvalitetu života u životnoj sredini. Pored toga, on pronalazi relevantnu literaturu u skladu sa interesovanjima učenika, čime se proširuju predviđeni sadržaji (Službeni glasnik RS, br. 12/18).

Zadatak nastavnika u okviru realizacije međupredmetne oblasti Obrazovanje za održivi razvoj je da pri planiranju nastave u operativne ciljeve predmeta koje predaju predvide i ciljeve međupredmetnih tema iz oblasti održivog razvoja. Tom prilikom oni se oslanjaju na korelacije (date za svaku međupredmetnu temu) koje ukazuju na povezanost ciljeva međupredmetne teme sa ciljevima pojedinih predmeta (Čabrilo i dr., 2015). U Metodološkom uputstvu za implementaciju programa Obrazovanje za održivi razvoj (ibid.) je istaknuta potreba za unapređivanjem kompetencija nastavnika koje se temelje na elementima: poznavanje tematike, konceptualno učenje, participacija, spremnost na saradnju, timski rad, empatija, motivacija i veštine organizacije.

Što se tiče međupredmetne teme Održivi razvoj, uloga nastavnika je da usmerava učenje i poučavanje i da motiviše učenike za aktivno učenje, rešavanje problema i praktično delovanje. Trebalo bi da se oslanja na metode koje naglašavaju samostalnost, preduzimljivost, empatiju i razvoj organizacionih sposobnosti i timskog rada. Prilikom grupnog rada, nastavnik mora voditi računa o individualnim razlikama među učenicima, o njihovim potrebama, interesima, sklonostima i mogućnostima, te da povremeno menja sastav grupe kako bi uticao na poboljšanje efikasnosti saradnje (Narodne novine, br. 7/2019). 
Ocenjivanje učenika

U okviru međupredmetne oblasti Obrazovanje za održivi razvoj u Crnoj Gori, ocenjivanje učenika je obavezno. Procenjuju se kompetencije učenika sa različitih aspekata, na osnovu kriterijuma: razumevanje sadržaja, znanje, uvažavanje različitih stanovišta i efikasno korišćenje komunikacionih strategija. Procenjivanje se može vršiti na osnovu: intervjua (između nastavnika i učenika ili učenika i učenika), žurnala (dokumentovanje razumevanja i saznanja o nekim događajima ili izazovima od strane učenika), kampanja (pokretanje kampanje preko društvenih mreža od strane učenika, sa ciljem unapređivanja lokalne zajednice), zapažanja nastavnika (o tome kako učenici komuniciraju međusobno, sa članovima zajednice), karakteristika procesnih veština (procenjivanje sposobnosti učenika za prikupljanje podataka, crtanje i tumačenje grafikona, precizno merenje i dr.), pisanih testova (provera znanja učenika o nekim događajima ili izazovima), komunikacije (praćenje sposobnosti učenika da komuniciraju znanja, ideje, vrednosti kroz npr. plakate, brošure, izveštaje, pesme, priče i dr.) i istraživanja (učenici sprovode istraživanje putem intervjua, ankete i sl. i obrađuju i analiziraju dobijene rezultate) (Čabrilo i dr., 2015).

Vrednovanje ostvarenosti predviđenih očekivanja za međupredmetnu temu Održivi razvoj u Hrvatskoj se vrši u okviru nastavnih predmeta i u okviru kurikuluma. U okviru nastavnih predmeta, procenjuju se postignuća učenika (znanja, veštine, stavovi), odnosno razvoj: kritičkog i kreativnog mišljenja; osećaja odgovornosti prema životnoj sredini, živim bićima i budućim generacijama i osećaja solidarnosti i spremnosti da se pruži pomoć; odgovarajućih veština za delovanje $i$ aktivnog odnosa prema održivom razvoju. Ocenjivanje se vrši metodama odabranim od strane nastavnika (npr. portfolio, učeničke mape, izveštaji), a o rezultatima se izveštava kontinuirano, pri čemu i učenici dobijaju povratnu informaciju o svom napredovanju. Na kraju svakog vaspitno-obrazovnog ciklusa, o ostvarenim rezultatima se izveštavaju učenici i njihovi roditelji na način koji odabere konkretna škola. Pored toga, na kraju svakog ciklusa može se vršiti i spoljašnje vrednovanje (Narodne novine, br. 7/2019).

Za izborni program Obrazovanje za održivi razvoj u Srbiji, u okviru Pravilnika o programu nastave i učenja za prvi razred gimnazije (Službeni glasnik RS, br. 12/18) nije posebno istaknut način evaluacije postignuća učenika. 


\section{ANALIZA I DISKUSIJA}

$\mathrm{Na}$ osnovu prikaza osobenosti obrazovanja za održivi razvoj u obrazovnim sistemima Srbije, Crne Gore i Hrvatske, izvršena je komparativna analiza prikazanih programa i predmeta sa aspekta tretiranh didaktičkih kategorija.

Nastavne teme $i$ sadržaji u kurikulumima sve tri zemlje pokazuju sličnost $\mathrm{u}$ smislu usmerenosti na sticanje osnovnih saznanja o čovekovom okruženju i odnosu ljudi prema životnoj sredini, kako bi se, kroz upoznavanje sa problemima savremenog društva, razvio kritički odnos i osnove aktivnog građanstva, te delovanje u korist budućeg održivog razvoja. S druge strane, analiza pokazuje da u oblasti sadržaja postoje značajne razlike. Razlike se ogledaju u tome što su sadržaji kurikuluma izbornog programa u Srbiji usmereni na lokalno okruženje, probleme sa kojima se učenici neposredno susreću, pre svega sa aspekta zaštite životne sredine, dok je međupredmetnim oblastima obuhvaćena i globalna perspektiva, osnove demokratije, ljudska prava, tolerancija, politički i ekonomski aspekti održivog razvoja. Samim tim, sadržaji su, ne samo kvantitativno, već i kvalitativno drugačiji, temeljniji, obuhvatniji. Ipak, kako je reč o međupredmetnim oblastima, a ne o posebnim predmetima, ostaje otvoreno pitanje nastavnikove umešnosti da učenicima približi date sadržaje, te pitanje mogućnosti da se njima posveti dovoljno pažnje i vremena.

U analizi ovog didaktičkog aspekta potrebno je osvrnuti se na specifičnost kurikuluma obrazovanja za održivi razvoj u Hrvatskoj gde je međupredmetna tema Održivi razvoj predstavljena kroz tri oblasti: povezanost, delovanje i dobrobit, pri čemu su, u okviru svake od njih dati obavezni i preporučeni sadržaji po razredima. Analizom datih sadržaja za svaku od ove tri oblasti, može se zaključiti da je cilj da se kod učenika postepeno razvija svest o povezanosti između samih ljudskih bića, kao i između ljudi i prirode; o tome kako ljudi međusobno deluju i kakav je antropogeni uticaj na životnu sredinu, te o načinima na koje ljudi mogu zaštititi prirodu i razvijati zdrave međuljudske odnose, utemeljene na razumevanju i poštovanju različitosti. Pored toga, sadržaji obuhvataju mnogobrojna ekonomska i politička pitanja, pa se može zaključiti da sadržaji obuhvataju sve tri dimenzije održivog razvoja: ekonomsku, društvenu i dimenziju zaštite životne sredine.

Način realizacije obrazovanja za održivi razvoj, dat u okviru izbornog programa/međupredmetnih oblasti, je u skladu sa zahtevima obrazovanja za održivi razvoj, ukoliko se pođe od toga da složenost problematike održivog razvoja nameće potrebu i za novim nastavnim metodama, pri čemu se preporučuju otkrivačko učenje, nasuprot reproduktivnom; istraživanje nasuprot jednosmernog prenošenja sadržaja; proučavanje stvarnosti naspram čitanja knjiga; aktivno učenje naspram 
pasivnog usvajanja informacija; produktivna akcija naspram reprodukcije činjenica; sticanje iskustava pre nego usvajanje znanja (Bosselmann, 2001). Realizacija obrazovanja za održivi razvoj u Srbiji, Crnoj Gori i Hrvatskoj je utemeljena na istim osnovama, s obzirom na to da je u svim programima/oblastima naglasak stavljen na iskustveno učenje, rešavanje problema, istraživačke, otkrivalačke i saradničke aktivnosti što doprinosi tome da učenik bolje upozna svoje okruženje, poveže teoriju sa praksom, razvije kritičko i stvaralačko mišljenje, kreativnost, kooperativnost i timski duh, aktivno slušajući druge i uvažavajući njihove predloge i ideje.

Osnovna razlika u aspektu realizacije obrazovanja za održivi razvoj proizilazi iz činjenice da je u Srbiji Obrazovanje za održivi razvoj poseban nastavni program, dok je u Crnoj Gori i Hrvatskoj reč o temi koja prožima sve nastavne predmete. Sa jedne strane, ovo može biti značajna prednost, jer su sadržaji izbornog programa u potpunosti posvećeni problemima održivog razvoja, te samim tim daju veće mogućnosti za detaljnije izučavanje definisanih tema. Sa druge strane, ako se uzme u obzir da reč je o programu izbornog tipa koji je dostupan samo učenicima gimnazija, smanjen je nivo dostupnosti ovih sadržaja u populaciji dece i mladih. Tako je upravo prednost međupredmetnih oblasti koje obuhvataju sve predmete u tome što omogućavaju učenicima svih uzrasta da sagledaju širinu problematike održivog razvoja. Ovo je veoma značajno, s obzirom na to da je ,obrazovanje za održivi razvoj dugotrajan proces, koji započinje u ranom detinjstvu i nastavlja se kroz više i obrazovanje za odrasle, a čak prevazilazi i granice zvaničnog obrazovanja“" (UNECE, 2005: 4).

Uloga nastavnika u konceptu obrazovanja za održivi razvoj je specifična jer zahteva nastavnika koji će preuzeti, može se reći, sporednu ulogu, ulogu savetnika, pomagača, saradnika, koji nije dominantno u centru učionice, ali koji je kompetentan i spreman na kontinuirano usavršavanje. Takve osobine nastavnika istaknute su u analiziranim kurikulumima obrazovanja za održivi razvoj: uloga nastavnika je da učenike podstakne na diskusiju, da im pomaže u svakoj fazi istraživačkog poduhvata (Srbija), da usmerava učenje i poučavanje, motiviše učenike za aktivno učenje, rešavanje problema i praktično delovanje (Hrvatska). Istaknuta je i potreba da nastavnik vodi računa o interesovanjima učenika (Srbija), odnosno o njihovim individualnim razlikama (Hrvatska). U kurikulumu obrazovanja za održivi razvoj u Crnoj Gori se posebno ukazuje na neophodnost kontinuiranog usavršavanja nastavnika, kako bi izgradili potrebne kompetencije za rad u oblasti obrazovanja za održivi razvoj. Pitanje nastavnikove kompetentnosti u ovoj oblasti je od ključnog značaja, jer je obrazovanje nastavnika za održivi razvoj 
preduslov kvalitetnog obrazovanja učenika za održivi razvoj. Obrazovanje za održivi razvoj zahteva nastavnike koji dobro poznaju održivost i obrazovanje za održivi razvoj, jer u suprotnom oni neće svoje predmete "protkati" održivim razvojem pomoću prigodnih nastavnih metoda (Svanström-Lozano-García, \& Rowe, 2008). Dok u Srbiji mogućnost da drže izborni program Obrazovanje za održivi razvoj imaju nastavnici biologije, hemije, fizike i geografije (Službeni glasnik RS, br. 13/18), u Crnoj Gori i Hrvatskoj međupredmetne oblasti i teme su dostupne svim predmetnim nastavnicima i zahtevaju razumevanje održivog razvoja i povezivanje sa sadržajima konkretnog predmeta.

Ocenjivanje učenika je pitanje značajnog nivoa složenosti u konceptu analiziranih kurikuluma. U okviru izbornog programa Obrazovanje za održivi razvoj (Srbija) nije posebno predviđen način ocenjivanja postignuća učenka, dok kurikulumi obrazovanja za održivi razvoj u Crnoj Gori i Hrvatskoj predviđaju procenjivanje specifičnih kompetencija. Tako je u Crnoj Gori, pored razumevanja i znanja, naglasak na učenikovom kreativnom izražavanju, na sposobnosti da svoje misli izrazi pisanim, praktičnim, usmenim putem, ali i na istraživačkim sposobnostima. U Hrvatskoj je ocenjivanje usmereno na procenu kritičkog mišljenja učenika, te njegovog odnosa prema drugima, prema sredini u kojoj živi i prema samom održivom razvoju.

Čini se da je pred nastavnike postavljena velika odgovornost, ne samo zbog specifičnosti načina ocenjivanja, već i zbog toga što se i ovde nameće pitanje njihove kompetentnosti u oblasti obrazovanja za održivi razvoj: koliko će kompetentno nastavnik moći da procenjuje kompetencije učenika u ovoj oblasti? Kako je svrha obrazovanja za održivi razvoj ne samo da učenici steknu znanja o održivom razvoju, već i da se podigne njihova svest i formiraju stavovi o značajnim pitanjima i problemima sa kojima se savremeni čovek suočava, te da se na osnovu toga pokrenu promene u njihovom ponašanju koje će biti u korist održivog razvoja, ocenjivanje ne sme biti marginalizovano. Reč je o obrazovanju „kojim se podstiču promene u znanjima, veštinama, vrednostima i stavovima sa ciljem stvaranja održivijeg i pravednijeg društva za sve“ (Leicht-Heiss, \& Byun, 2018: 7). Ovako važan, globalan cilj obrazovanja za održivi razvoj nameće potrebu za kontinuiranim praćenjem i vrednovanjem kompetencija učenika za održivi razvoj.

\section{ZAKLJUČAK}

U radu je predstavljen komparativni prikaz i analiza obrazovanja za održivi razvoj sa posebnim osvrtom na nastavne teme i sadržaje, način realizacije, ulogu nastavnika i ocenjivanje učenika u okviru izbornog programa Obrazovanje za 
održivi razvoj (Srbija), međupredmetne oblasti Obrazovanje za održivi razvoj (Crna Gora) i međupredmetne teme Održivi razvoj (Hrvatska). Sprovedena analiza je pokazala sledeće:

- $\quad$ sadržaji obrazovanja u Crnoj Gori i Hrvatskoj obuhvataju sve dimenzije održivog razvoja: ekonomsku, društvenu i dimenziju zaštite životne sredine, što je omogućeno time što je obrazovanje u oblasti održivog razvoja postavljeno dovoljno široko, tako da obuhvati i osnovno i srednje obrazovanje. U Srbiji to nije slučaj, jer je izborni program Obrazovanje za održivi razvoj novina, te dominira upoznavanje sa dimenzijom zaštite životne sredine, ali se očekuje da će koncepcije programa za 2., 3. i 4. razred gimnazije omogućiti postepeno upoznavanje sa svim aspektima održivog razvoja;

- realizacija obrazovanja za održivi razvoj, pored očiglednih razlika između obrazovanja za održivi razvoj kao izbornog programa i kao međupredmetne oblasti, ima i zajedničku karakteristiku, a to je stavljanje učenika u poziciju aktivnog učesnika obrazovanja, suočavanje sa realnim životnim situacijama, rešavanje problema, istraživanje i osmišljavanje predloga za unapređivanje kvaliteta života i zaštitu životne sredine;

- nastavnik je i u okviru izbornog programa u Srbiji, i u okviru međupredmetnih oblasti u Crnoj Gori i Hrvatskoj, predstavljen kao pomagač, saradnik, kao neko ko usmerava učenike na samostalno istraživanje i dolaženje do rešenja;

- ocenjivanje učenika u Crnoj Gori i Hrvatskoj je usmereno je na evaluaciju učenikovog promišljanja problematike koju pokriva održivi razvoj, sposobnosti, te odnosa koji uspostavljaju sa drugima, dok način ocenjivanja u okviru izbornog programa u Srbiji nije posebno (jasno) istaknut, odnosno specifikovan;

Posmatrano sa aspekta utvrđenih rezultata i iznetih zaključaka, svako dalje promišljanje o konceptu obrazovanja za održivi razvoj na Balkanu može se temeljiti na predstavljenim činjenicama, $u$ smislu njihovog daljeg istraživanja, ali $i$ implementiranja $\mathrm{u}$ nove obrazovne politike. U cilju unapređivanja istraživane oblasti mogu se definisati sledeće implikacije i preporuke: (1) neophodno je obezbediti viši nivo podrške i osnaživanja nastavnika za kompetentno realizovanje nastave u oblasti održivog razvoja; (2) potrebno je kontinuirano i sistematsko usavršavanje nastavnika u didaktičko-metodičkoj i dokimološkoj oblasti; (3) sistematski raditi na izradi, inoviranju i usavršavanju nastavnog programa za 
predmet Obrazovanje za održivi razvoj za više razrede gimnazije; (4) kreirati osnovu (predlog) za novu obrazovnu politiku u Srbiji kojom bi se u modifikovanom i prilagođenom obliku implementirali efikasni modeli međupredmetnog pristupa obrazovanja za održivi razvoj iz okruženja, u našim osnovnim školama; (5) distribuirati i predstaviti primere dobre prakse Hrvatske i Crne Gore u ovoj oblasti realizatorima izbornog predmeta Obrazovanje za održivi razvoj u Srbiji; (6) istražiti prednosti i nedostatke prikazanih kurikulima iz perspektive učenika i nastavnika.

Tamara Vukić, Marija Jovanović

\section{DIDACTICAL ASPECTS OF REALIZATION OF EDUCATION FOR SUSTAINABLE DEVELOPMENT IN THE MODERN SCHOOL CURRICULA}

\section{Summary}

The focus of the paper is the content of education for sustainable development in the curricula in Serbia, Montenegro and Croatia. The paper is based on a comparative analysis of the following curricula: the curriculum of the elective program Education for Sustainable Development for Serbiangrammar schools, the curriculum for the interdisciplinary field of Education for Sustainable Development in Montenegro and the curriculum for the interdisciplinary theme Sustainable Development in Croatia. The analysis was conducted by comparing the following didactical aspects: teaching topics and contents, ways of realization, teacher's role, and ways of assessment presented in these curricula. The results showed that the scope of contents of education for sustainable development in Montenegro and Croatia is much wider than that in the elective program in Serbia, as they include all three dimensions of sustainable development: economic, social and environmental. The student is presented as an active subject in each of these curricula, as someone who finds solutions to various problems by experiencing real-life situations, and therefore aquiring skills necessary for living in a modern society, while the teacher's role is represented as supporting: the teacher is an assistant and a collaborator. The assessment of the students' achievements in interdisciplinary fields is oriented towards the evaluation of the students' reflections on the sustainable development problems, their abilities, and their relations with others, while the way of assessment in Serbia is not particularly emphasised.

Key words: didactical aspect, education, sustainable development, curricula, modern school.

\section{LITERATURA}

Bagoly-Simó, P. (2013). Tracing Sustainability: An International Comparison of ESD Implementation into Lower Secondary Education. Research, 7(1), 95-112. 
Benavot, A. (2014). Education for Sustainable Development in Primary and Secondary Education. Preuzeto 23. jula 2019, sa https://www.researchgate.net/publication/282342116_Education_for_Sustain able_Development_in_Primary_and_Secondary_Education

Bosselmann, K. (2001). University and Sustainability: Compatible Agendas?. Educational Phylosophy and Theory, 33(2), 167-186.

Čabrilo, N.-Grbović, S.-Lalović, Z.-Đorđević, J.-Kaluđerović, S.-Gligorović, B. i Radusinović, M. (2014a). Međupredmetne oblasti u predmetnim programima: osnovna škola. Podgorica: Zavod za školstvo.

Čabrilo, N.-Grbović, S.-Lalović, Z.-Novović, R.-Đorđević, J. i Vušurović, M. (2014b). Međupredmetne oblasti u predmetnim programima: opšta gimnazija. Podgorica: Zavod za školstvo.

Čabrilo, N.-Lalović, Z.-Sudar, S. i Vasiljević, M. (2015). Metodološko uputstvo za implementaciju programa Obrazovanje za održivi razvoj. Podgorica: Zavod za školstvo.

Calder, W.-Clugston, R. M. (2003). International Efforts to Promote Higher Education for Sustainable Development. Planning for Higher Education, 31(3), 34-48.

Ceulemans, K.-De Prins, M. (2010). Teacher's Manual and Method for SD Integration in Curricula. Journal of Cleaner Production, 18, 645-651.

Development 2005-2014: Draft International Implementation Scheme. Preuzeto 10. jula 2019, sa https://unesdoc.unesco.org/ark:/48223/pf0000139937? posInSet=2\&queryId=cbeadd55-351a-4aa8-8a3d-b167cd1b5574

Didham, R. J.-Ofei-Manu, P. (2015). The Role of Education in the Sustainable Development Agenda: Empowering a Learning Society for Sustainability through Quality Education. In: Bengtsson, M., Olsen, H. \& Zusman, E. (eds.) (2007) Achieving the Sustainable Development Goals: From Agenda to Action. Kamiyamaguchi, Hayama, Kanagawa, Japan: Institute for Global Environment Strategies. 93-129.

Ifegbesan, A.-Lawal, M. B. \& Rampedi, I. T. (2017). The Nigeria Teachers Social Studies Training Curriculum and Sustainable Development Goals: A Content Analysis. Journal of International Social Studies, 7(1), 92-122.

Leicht, A.-Heiss, J. \& Byun, W. J. (2018). Issues and Trends in Education for Sustainable Development. Place de Fontenoy, Paris: UNESCO.

Martins, A. A.-Mata, T. M. \& Costa, C. A. V. (2006). Education for Sustainability: Challenges and Trends. Clean Technologies and Environmental Policy, 8, 31-37. doi:10.1007/s10098-005-0026-3 
Mulà, I.-Dlouhý, J. \& Alba, D. (2017). Catalysing Change in Higher Education for Sustainable Development: A Review of Professional Development Initiatives for University Educators. International Journal of Sustainability in Higher Education, 18(5), 798-820. doi:10.1108/IJSHE-03-2017-0043

Odluka o donošenju kurikuluma za međupredmetnu temu Održivi razvoj za osnovne i srednje škole u Republici Hrvatskoj, Narodne novine, br. 7/2019. Preuzeto 09. avgusta 2019, sa https://narodne-novine.nn.hr/clanci/sluzbeni/2019_01_ 7_152.html

Osman, A.-Ladhani, S.-Findlater, E. \& McKay, V. (2017). Curriculum Framework for the Sustainable Development Goals. Commonwealth Secretariat. Preuzeto 02. jula 2019, sa https://www.thecommonwealth-educationhub.net/wpcontent/uploads/2017/01/Curriculum_Framework_for_SDGs_July_2017.pdf

Pravilnik o dopunama Pravilnika o stepenu i vrsti obrazovanja nastavnika, stručnih saradnika i pomoćnih nastavnika u gimnaziji, Službeni glasnik RS, god. 57, br. $13 / 18$.

Pravilnik o dopuni pravilnika o nastavnom planu i programu stručnih predmeta srednjeg stručnog obrazovanju u području rada Hemija, nemetali i grafičarstvo, Službeni glasnik RS, god. 64, br.12/15.

Pravilnik o dopuni pravilnika o nastavnom planu i programu stručnih predmeta srednjeg stručnog obrazovanju u području rada Šumarstvo i obrada drveta, Službeni glasnik RS, god. 64, br. 6/15.

Pravilnik o izmeni i dopunama pravilnika o nastavnom planu i programu srednjeg stručnog obrazovanja u području rada Ekonomija, pravo i administracija, Službeni glasnik RS, god. 64, br. 15/15.

Pravilnik o nastavnom planu i programu stručnih predmeta srednjeg stručnog obrazovanju u području rada Geologija, rudarstvo i metalurgija, Službeni glasnik $R S$, god. 66, br. 5/17.

Pravilnik o planu i programu nastave i učenja stručnih predmeta srednjeg stručnog obrazovanja u području rada Geodezija i građevinarstvo, Službeni glasnik RS, god. 67 , br. $7 / 18$.

Pravilnik o Planu nastave i učenja za peti i šesti razred osnovnog obrazovanja i vaspitanja i programu nastave i učenja za peti i šesti razred osnovnog obrazovanja i vaspitanja, Službeni glasnik $R S$, god. 67, br. 15/18.

Pravilnik o Planu nastave i učenja za prvi ciklus osnovnog obrazovanja i vaspitanja i programu nastave i učenja za prvi razred osnovnog obrazovanja i vaspitanja, Službeni glasnik RS, god. 66, br. 10/17. 
Pravilnik o Programu nastave i učenja za četvrti razred osnovnog obrazovanja i vaspitanja, Službeni glasnik RS, god. 68, br. 11/19.

Pravilnik o Programu nastave i učenja za drugi razred osnovnog obrazovanja i vaspitanja, Službeni glasnik RS, god. 67, br. 16/18.

Pravilnik o Programu nastave i učenja za osmi razred osnovnog obrazovanja i vaspitanja, Službeni glasnik $R S$, god. 68, br. 11/19.

Pravilnik o Programu nastave i učenja za prvi razred gimnazije, Službeni glasnik RS, god. 67, br. 12/18.

Pravilnik o Programu nastave i učenja za sedmi razred osnovnog obrazovanja i vaspitanja, Službeni glasnik $R S$, god. 68, br. 5/19.

Pravilnik o Programu nastave i učenja za treći razred osnovnog obrazovanja i vaspitanja, Službeni glasnik $R S$, god. 68, br. 5/19.

Rieckmann, M. (2012). Future-Oriented Higher Education: Which Key Competencies Should be Fostered Through University Teaching and Learning? Futures, 44(2), 127-135. doi:10.1016/j.futures.2011.09.005

Stanišić, J. M. (2016). Characteristics of Teaching Environmental Education in Primary Schools. Inovacije $u$ nastavi, 29(4), 87-100. doi:10.5937/inovacije1604087S

Svanström, M.-Lozano-García, F. J. \& Rowe, D. (2008). Learning Outcomes for Sustainable Development in Higher Education. International Journal of Sustainability in Higher Education, 9(3), 339-351.

Taylor, N.-Quinn, F.-Jenkins, K.-Miller-Brown, H.-Rizk, N.-Prodromou, T. ... \& Taylor, S. (2019). Education for Sustainability in the Secondary Sector - A Review. Research, 13(1), 102-122. doi:10.13140/RG.2.1.1978.9283.

UN (2005). The UN Decade of Education for Sustainable Development (2005-2014): International Implementation Scheme. Preuzeto 24. jula 2019, sa https://unesdoc.unesco.org/ark:/48223/pf0000139937.

UN (2015). Transforming Our World: the 2030 Agenda for Sustainable Development. Preuzeto 07. juna 2019, sa https://undocs.org/A/RES/70/1.

UNECE (2005). UNECE Strategija obrazovanja za održivi razvoj. Preuzeto 20. aprila 2020, sa https://www.unece.org/fileadmin/DAM/env/esd/ strategytext/ StrategyinSebian.pdf

UNESCO (2005). United Nations Decade of Education for Sustainable Development 2005-2014: Draft International Implementation Scheme. Preuzeto 10. jula 2019, sa https://unesdoc.unesco.org/ark:/48223/pf0000139937?posInSet=2\& queryId=cbeadd55-351a-4aa8-8a3d-b167cd1b5574 